\title{
ĐÁNH GIÁ HIỆN TRẠNG VÀ ĐỀ XUẤT GIẢI PHÁP NÂNG CAO HIẸU QUẢ QUẢN LÝ CHẤT THẢI RẮN SINH HOẠT TRÊN ĐỊA BÀN HUYỆN ĐAN PHƯỢG, THÀNH PHỐ HÀ NỘI
}

\author{
Phạm Thị Tố Oanh ${ }^{1}$
}

Tóm tắt: Huyện Đan Phượn, thành phố Hà Nội với lượng chất thải rắn sinh hoạt vớc khoảng 88 tấn/ngày. Lượng CTRSH được thu gom chiếm 90\%. Hệ số phát sinh CTRSH trên đầu người trung bình là $0,58 \mathrm{~kg} /$ nguời/ngày. Thành phần hũu co chiếm 50\% - 54\%. Các thành phần còn lại chiếm tỷ lệ nhỏ (nhu nilon, nhựa là 11,5\% - 14,5\%). Kết quả điều tra cho thấy, 90\% nguời dân đánh giá thời gian và tần suất thu gom hợp lý, công tác thu gom đạt hiệu quả, đảm bảo mỹ quan đô thị. Chất thải rắn hiện nay chưa được phân loại rác tại nguồn và sau thu gom được chuyển đến nhà máy xủ lý và chế biến rác Phuơng Đình để xử lý bằng phương pháp đốt. Tuy nhiên công tác quản lý CTRSH còn hạn chế trong hệ thống quy định, thông tin, tuyên truyền, chura có định huớng phù hợp xu huớng gia tăng lượng thải, hạn chế trong quản lý khu vục tập kết và xử lý chất thải... Các giải pháp về chính sách; nâng cao năng lực của hệ thống quản lý nhà nước về bảo vệ môi trương nhu tuyên truyền giáo duc, nâng cao nhận thức; công nghệ, vị trí tập kết và trạm trung chuyển, xủ lý chất thải theo công nghệ tiên tiến đã được đề xuất nhằm nâng cao hiệu quả quản lý chất thải rắn sinh hoạt trên địa bàn huyện. Nghiên cưu này đánh giá hiện trạng và giải pháp quản lý ở quy mô cấp huyện sẽ góp phần là bài hoc tốt có ý nghĩa để quản lý CTRSH quy mô lớn hơn trên địa bàn thành phố Hà Nội.

Từ khóa: Chất thải rắn sinh hoạt, Hiện trạng, Giải pháp, Quản lý, Xủ lý.

Ban Biên tập nhận bài: 12/4/2020

Ngày phản biện xong: 20/5/2020

Ngày đăng bài: 25/5/2020

\section{1. Đặt vấn đề}

Hiện nay, thu gom, phân loại rác thải, chôn lấp chất thải rắn sinh hoạt (CTRSH) hoạt được sử dụng chủ yếu ở các nước đang phát triển nhưng phải tuân thủ các quy định về bảo vệ môi trường một cách nghiêm ngặt. Phương pháp xử lý rác bằng phương pháp đốt thường được sử dụng với hiệu quả và chi phí cao, làm giảm tới mức tối thiểu chất thải rắn. Công nghệ đốt rác thường sử dụng ở các quốc gia phát triển vì phải có một nền kinh tế đủ mạnh để bao cấp cho việc thu đốt chất thải rắn sinh hoạt bao gồm nhiều chất thải khác nhau sinh khói độc và dễ sinh khí đioxin nếu không giải quyết tốt việc xử lý khói. Năng lượng phát sinh khi đốt rác có thể tận dụng cho các lò hơi, lò sưởi hoặc cho ngành công nghệ

${ }^{1}$ Liên minh Hợp tác xã Việt Nam

Email:oanhpt@vca.org.vn nhiệt và phát điện. Phương pháp ủ hữu cơ từ rác hữu cơ (sản xuất phân bón hữu cơ) là một phương pháp truyền thống được áp dụng phổ biến ở các quốc gia đang phát triển trong đó có Việt Nam.

Ở nước ta, 15/16 tỉnh, thành phố có bãi chôn lấp hợp vệ sinh. Theo thống kê, có 149 bãi rác cũ không hợp vệ sinh (21 bãi cấp tỉnh, thành phố và 128 bãi cấp huyện, thị trấn). Nước ta hiện có 10 nhà máy chế biến chất thải rắn sinh hoạt có thành phần hữu cơ cao thành phân bón vi sinh tại Cầu Diễn (Hà Nội), nhà máy xử lý rác thải Nam Định, nhà máy xử lý rác thải Bà Rịa - Vũng Tàu, nhà máy Đông Vinh (Vinh), Thủy Phương (Huế) và Ninh Thuận hoàn toàn do Việt Nam tự nghiên cứu và chế tạo. Xu hướng đầu tư đại trà lò đốt 
CTRSH ở tuyến huyện, xã là phổ biến. Trên cả nước có khoảng 50 lò đốt đa số cỡ nhỏ, công suất xử lý dưới $500 \mathrm{~kg} /$ giờ. Trong đó có khoảng $2 / 3$ lò đốt được sản xuất, lắp ráp trong nước. Một số cơ sở xử lý CTRSH sử dụng công nghệ đốt công suất lớn, hiện đang hoạt động: Nhà máy xử lý chất thải Sơn Tây thuộc Công ty cổ phần dịch vụ môi trường Thăng Long; Xí nghiệp xử lý CTRSH và sản xuất phân bón tại cụm công nghiệp Phong Phú thuộc Công ty TNHH MTV môi trường đô thị Thái Bình;... [4]

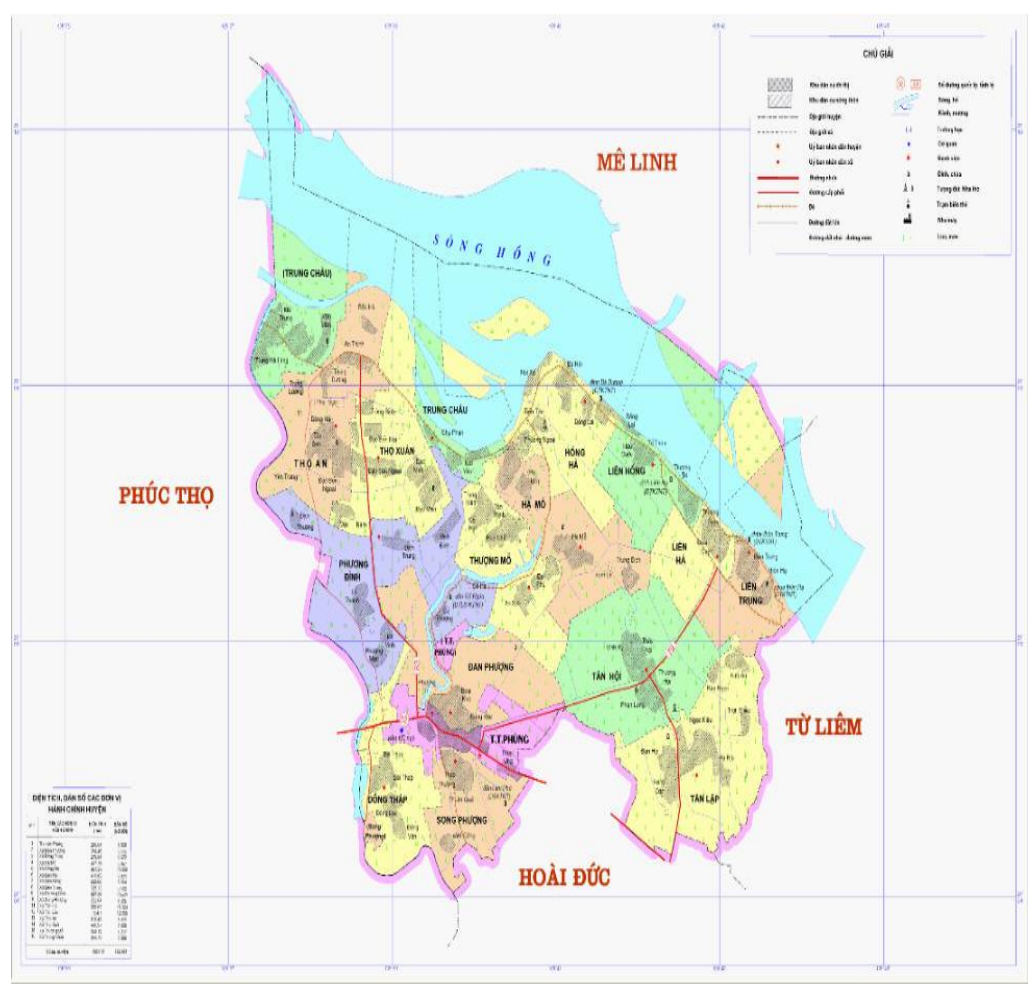

Hình 1. Vị trí khu vục nghiên cứu

Đan Phượng là một trong 30 quận, huyện của thủ đô Hà Nội, nằm ở phía Tây Bắc của thành phố Hà Nội, tại khoảng giữa của trục đường Quốc lộ 32 từ trung tâm Hà Nội đi Sơn Tây, tổng diện tích tự nhiên là $77,35 \mathrm{~km}^{2}$; cơ cấu hành chính gồm 15 xã và 01 thị trấn, 120 thôn, cụm dân cư, 06 tổ dân phố, dân số trên 169.000 người. Phía Đông giáp các huyện Đông Anh (ranh giới tự nhiên là sông Hồng) và quận Bắc Từ Liêm. Phía Bắc giáp huyện Mê Linh có dòng sông Hồng cắt ngang làm ranh giới. Phía Tây giáp huyện Phúc Thọ. Phía Nam giáp huyện Hoài Đức [1,7]. Với lợi thế đặc biệt về vị trí địa lý, Đan Phượng sẽ có nhiều cơ hội mở rộng thị trường, giao lưu hàng hóa và thu hút đầu tư cho phát triển toàn diện về kinh tế - xã hội. Cùng với quá trình công nghiệp hóa, hiện đại hóa của huyện là sự gia tăng nhanh chóng lượng CTRSH, với 88 tấn/ngày $[3,8]$.
Rác thải chỉ được thu gom tập trung ở một số bãi rác lộ thiên, không tiến hành xử lý, chôn lấp, làm mất vệ sinh công cộng, mất mỹ quan môi trường, gây ô nhiễm môi trường đất, nước, không khí. Đặc biệt, những bãi rác này còn là nguy cơ gây bệnh dịch, nguy hại đến sức khỏe con người $[4,5]$. Vì vậy, đánh giá hiện trạng và đề xuất giải pháp nâng cao hiệu quả quản lý CTRSH trên địa bàn huyện Đan Phượng, thành phố Hà Nội là nghiên cứu mang tính cấp thiết.

\section{Phương pháp nghiên cứu}

- Phương pháp thu thập thông tin nhằm tổng hợp cơ sở dữ liệu thu thập các số liệu về điều kiện tự nhiên và kinh tế - xã hội về hiện trạng CTRSH huyện Đan Phượng.

- Phương pháp điều tra khảo sát bằng phiếu điều tra, tham vấn cộng đồng để khảo sát nhận thức, đánh giá về công tác quản lý CTRSH của các hộ gia đình và các cán bộ môi trường đô thị 
(cán bộ quản lý, công nhân thu gom, thu phí vệ sinh) tại khu vực nghiên cứu. Thực hiện 160 phiếu (40 phiếu/thị trấn/xã) với 2 mẫu phiếu điều tra cho 2 nhóm đối tượng cụ thể là nhân viên đơn vị thu gom xử lý CTRSH và cộng đồng người dân $[2,6]$.

- Phương pháp điều tra xác định hệ số phát sinh và thành phần $\mathrm{CTRSH}$ : Mỗi xã/thị trấn nghiên cứu lựa chọn ngẫu nhiên 08 hộ, tiến hành phát túi cho các hộ đựng rác và đến cân vào cùng giờ ngày hôm sau (thực hiện cân 10 lần/tháng $\mathrm{x}$ 3 tháng). Sử dụng cân để xác định khối lượng rác bằng phương pháp khối lượng. Ghi lại trọng lượng rác và số nhân khẩu của từng hộ và tính hệ số phát sinh rác thải. Hệ số phát sinh rác $=($ trọng lượng rác của hộ)/(số nhân khẩu)

Xác định thành phần CTRSH: Các mẫu rác

$$
\text { Thành phần \% theo loại }=\frac{\text { Trọng lượng theo từng loại }}{\text { Tổng lượng rác thải của lấy mẫu }} \times 100 \%
$$

- Phương pháp dự báo

Dự báo về khối lượng CTRSH của huyện Đan Phượng đến năm 2025.

Tốc độ tăng dân số được dự báo bằng phương pháp Euler (theo mô hình Euler cải tiến) qua công thức gần đúng: $\mathrm{N}_{\mathrm{i}+1}=\mathrm{N}_{\mathrm{i}}+\mathrm{r} \cdot \mathrm{N}_{\mathrm{i} .} \Delta \mathrm{t}$ (người)

Trong đó $\mathrm{N}_{\mathrm{i}}$ là số dân ban đầu (người); $\mathrm{N}_{\mathrm{i}+1}$ là số dân sau một năm (người); $r$ là tốc độ tăng dân số. Với $r=1,02 \%$ (2020), $r=0,95 \%$ (20212025); $\Delta \mathrm{t}$ là khoảng thời gian dự báo (năm).

* Lượng chất thải rắn sinh hoạt phát sinh:

$\mathrm{R}_{\mathrm{SH}}=\mathrm{N}_{\mathrm{i}+1} \cdot \mathrm{g} \cdot 365 / 1000$ (tấn/năm)

Trong đó $\mathrm{R}_{\mathrm{SH}}$ là lượng CTRSH trong giai đoạn đang xét (tấn/năm); $\mathrm{N}_{\mathrm{i}+1}$ là số dân trong giai đoạn đang xét (người); $\mathrm{g}$ là tiêu chuẩn thải rác ( $\mathrm{kg} /$ người/ngày đêm).

* Lượng chất thải rắn sinh hoạt được thu gom: $\mathrm{R}_{\mathrm{TG}}=\mathrm{R}_{\mathrm{SH}} \times \mathrm{P}$

Trong đó $\mathrm{P}$ là tỷ lệ thu gom (\%/năm)

- Phương pháp thống kê và xử lý thông tin: Toàn bộ các số liệu được thực hiện trên các bảng biểu và đồ thị. Số liệu được quản lý và phân tích với phần mềm Microsoft Excel và phần mềm soạn thảo văn bản Microsoft Word.

- Phương pháp chuyên gia: Tổng hợp, phân tích từ ý kiến chuyên gia trong tổ chức triển khai, thải lấy từ các hộ đã lựa chọn tại 4 xã/thị trấn sau khi được cân đề xác định tỷ lệ phát sinh CTRSH thì sẽ đem thu gom lại một chỗ riêng. Tại mỗi điểm tập trung chất thải ấy, tiến hành trộn đều thành đống hình côn nhiều lần. Chia hình côn đã trộn đều làm 4 phần bằng nhau. Lấy 2 phần chéo nhau và tiếp tục trộn thành đống hình côn mới. Tiếp tục thực hiện các thao tác trên cho đến khi đống rác còn lại khoảng $10 \mathrm{~kg}$ thì tiến hành phân loại thủ công thành các loại: Chất hữu cơ; Giấy, bìa các loại; Nhựa, túi nilon; Thủy tinh; Kim loại; Khác. Sau đó, sử dụng cân xác định và ghi lại trọng lượng của từng loại và tính tỷ lệ \% thành phần từng loại.

Tại mỗi xã/thị trấn tiến hành lấy rác và phân loại rác vào 3 ngày: thứ 2 , thứ 5 , thứ 7 trong vòng 4 tuần.

phương pháp lấy mấu, tính toán và dự báo.

\section{Kết quả và thảo luận}

\subsection{Nguồn gốc, thành phần và hệ số phát} sinh chất thải rắn sinh hoạt

Từ nguồn số liệu sơ cấp cho thấy CTRSH ở huyện Đan Phượng được phát sinh từ nhiều nguồn khác nhau từ khu dân cư (là chủ yếu), khu thương mại, văn phòng công sở, dịch vụ đô thị,...

Hệ số phát sinh CTRSH (kg/người/ngày)

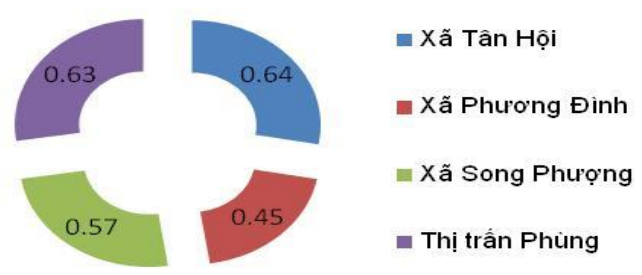

Hình 2. Hệ số phát sinh chất

Từ kết quả điều tra thực tế tại khu vực nghiên cứu gồm 4 xã/thị trấn ( xã Tân Hội, xã Phương Đình, xã Song Phượng, thị trấn Phùng) có tổng số dân là 46.886 người. Lượng CTRSH phát sinh khoảng 27,2 tấn/ngày, chiếm khoảng 32,4\% tổng lượng CTRSH của toàn huyện Đan Phượng (Bảng 2). Trung bình một ngày tại khu vực nghiên cứu lượng $\mathrm{CTRSH}$ được thải ra là 
$0,58 \mathrm{~kg} /$ người/ngày.

Trong đó, xã Tân Hội và thị trấn Phùng có lượng CTRSH phát sinh nhiều do dân số đông và tập trung nhiều hộ gia đình buôn bán. Dân cư tại các khu vực này tiêu thụ các mặt hàng thực phẩm và các mặt hàng phục vụ cho sinh hoạt gia đình lớn, do đó lượng CTRSH phát sinh hàng ngày cao hơn nhiều so với các khu vực tập trung ít dân cư. Xã Song Phượng có dân số ít nên lượng rác phát sinh ít hơn nhiều so với các xã/thị trấn còn lại [9].

Bảng 1. Các nguồn và thành phần chất thải rắn tại huyện Đan Phuợng

\begin{tabular}{|c|c|c|c|}
\hline \multicolumn{2}{|c|}{ Loại nguồn thải } & Thành phần & Số lượng \\
\hline Khu dân cư & Hộ gia đình & $\begin{array}{l}\text { Thực phẩm dư thừa, bao bì, hàng hóa, đồ dùng, chất } \\
\text { thải hóa chất tẩy rửa, pin,.. }\end{array}$ & 32.862 \\
\hline $\begin{array}{l}\text { Khu thương } \\
\text { mại }\end{array}$ & Chợ, siêu thị & Giấy, nhựa, thủy tinh, kim loại,.... & 18 \\
\hline \multirow{4}{*}{$\begin{array}{l}\text { Văn phòng } \\
\text { công sở }\end{array}$} & $\begin{array}{l}\text { Bệnh viện, } \\
\text { trạm y tế }\end{array}$ & Giấy, nhựa, thủ tinh, băng, gạc, phế phẩm bệnh,... & 17 \\
\hline & Trường học & Giấy, nhựa, thủy tinh, kim loại,.... & 58 \\
\hline & Cơ quan & Giấy, nhựa, thủy tinh, kim loại,.... & 26 \\
\hline & Doanh nghiệp & Giấy, nhựa, thủy tinh, kim loại,.... & 744 \\
\hline \multirow{2}{*}{ Dịch vụ đô thị } & Nhà hàng & Đồ ăn thừa, giấy, nhựa, thủy tinh, kim loại,.... & 35 \\
\hline & Nhà nghỉ & Thực phẩm, giấy, nhựa, thủy tinh, kim loại,... & 27 \\
\hline Khu sản xuất & Nông nghiệp & Phân, rơm rạ, bao bì,... & 43 \\
\hline
\end{tabular}

Bảng 2. Lượng CTRSH phát sinh tù̀ các hộ gia đình tại khu vực nghiên cứu

\begin{tabular}{clcccc}
\hline \multirow{2}{*}{ STT } & Xã/thị trấn & Dân số & $\begin{array}{c}\text { Hệ số phát sinh } \\
\text { (kg/người/ngày) }\end{array}$ & & \multicolumn{2}{c}{ Tấn/ngàny } & Tấn/năm \\
\hline 1 & Thị trấn Phùng & 10.195 & 0,63 & 6,42 & $2.344,340$ \\
2 & Tân Hội & 19.698 & 0,64 & 12,61 & $4.601,453$ \\
3 & Phương Đình & 12.565 & 0,45 & 5,65 & $2.063,801$ \\
4 & Song Phượng & 4.428 & 0,57 & 2,52 & 921,245 \\
& Tổng & 46.886 & & 27,2 & $9.930,839$ \\
\hline
\end{tabular}

3.2. Thành phần chất thải rắn sinh hoạt trên chất dẻo: chai lọ, hộp, can nhựa, túi nilon,... cũng địa bàn huyện Đan Phượng chiếm tỷ lệ khá cao (khoảng 11,5 - 14,5\%).

Thành phần chất hữu cơ dễ phân hủy chiếm tỷ Thành phần rác thải tại mỗi xã/thị trấn được thể lệ cao nhất (chiếm hơn 50\%). Thành phần nhựa, hiện ở bảng 3.

Bảng 3. Thành phần CTRSH của các xã trên địa bàn nghiên cưu

\begin{tabular}{lccccc}
\hline \multicolumn{1}{c}{ Thành phần chất thải } & Đơn vị & TT Phùng & Xã Tân & Xã Phương & Xã Song \\
\hline Chất hữu cơ dễ phân hủy (thức & $\%$ & 54,33 & 53,5 & 52,67 & 50,67 \\
Giấy, bìa, vải vụn các loại & $\%$ & 3,83 & 4,5 & 4,67 & 3,37 \\
Nhựa, chất dẻo (chai nhựa, túi & $\%$ & 14,5 & 13,33 & 11,5 & 13,83 \\
Thủy tinh (chai lọ, cốc vớ,...) & $\%$ & 6,83 & 5,5 & 3,67 & 4,33 \\
Kim loại (vỏ hộp, sợi kim & $\%$ & 5,67 & 4,5 & 6,33 & 3,83 \\
Khác (xỉ than, đá, gạch vụn, & $\%$ & 14,83 & 18,67 & 21,17 & 23,97 \\
\multicolumn{1}{c}{ Tổng } & $\mathbf{\%}$ & $\mathbf{1 0 0}$ & $\mathbf{1 0 0}$ & $\mathbf{1 0 0}$ & $\mathbf{1 0 0}$ \\
\hline
\end{tabular}

Công tác phân loại rác tại nguồn trên địa bàn huyện chưa được áp dụng phổ biến, tất cả chất 
thải phát sinh trong quá trình sinh hoạt đều được đổ tập trung với nhau.

\subsection{Thu gom CTRSH trên địa bàn huyện Đan Phương}

Rác sinh hoạt với nhiều thành phần khác nhau được người dân cho chung vào một túi hoặc thùng chứa rồi mang đổ ra xe rác, vì vậy mà hình thức thu gom rác đơn vị thu gom áp dụng đó là thu gom tập trung. Đối với hình thức thu gom này đòi hỏi hoạt động thu gom rác tại các hộ gia đình phải diễn ra liên tục hàng ngày vì lượng rác tập trung là khá lớn. Hình thức thu gom rác hiện nay mà đơn vị thu gom áp dụng chủ yếu bằng phương pháp thủ công. Đối với CTRSH tại hộ gia đình, công nhân trực tiếp đẩy xe gom tới từng tuyến phố, ngõ xóm để thu gom rác. Đối với rác đường phố, cơ quan, trường học, bệnh viện, siêu thị, chợ... được nhân viên quét dọn và để vào thùng rồi mang bãi tập kết. Quy trình thu gom và vận chuyển CTRSH ở huyện Đan Phượng thể hiện ở hình 3.

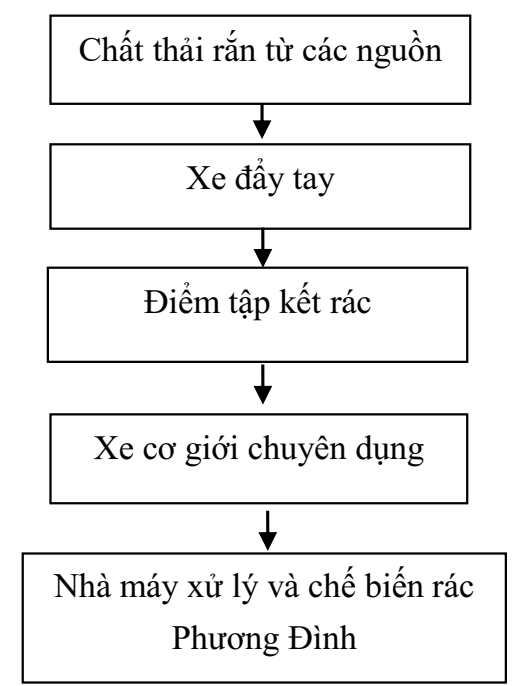

Hình 3. So đồ quy trình thu gom, vận chuyển chất thải rắn sinh hoạt

Rác thải được thu gom vào chiều tối từ 4 giờ 30 giờ - 6 giờ 30 phút, với tần suất là $1-2$ ngày/lần. Ngoài ra còn có một lực lượng công nhân quét dọn để duy trì vệ sinh đường phố. Trong những thời điểm lượng rác tăng cao so với những ngày thường như các ngày cuối tuần, lễ tết,... các công nhân vệ sinh môi trường và công nhân vận chuyển phải tăng ca làm việc để đảm bảo hoàn thành công việc, giữ gìn vệ sinh môi trường.

Tại các xã/thị trấn, các công nhân thu gom rác được phân công thu gom rác, duy trì vệ sinh các tuyến đường, hè phố, ngõ xóm theo các tuyến thu gom. Qua điều tra 4 xã/thị trấn, tuyến thu gom tại mỗi xã/thị trấn. Thị trấn Phùng có 18 người thu gom với 7 tuyến thu gom hàng ngày trên các đường, vỉa hè, ngõ phố. Rác sau khi được thu gom theo các tuyến, được đưa đến điểm tập kết công an thị trấn (Kí hiệu trên sơ đồ: TKTTP) để xe vận chuyển rác tới nhà máy xử lý. Tuyến 1 : duy trì vệ sinh tuyến đường quốc lộ 32 (khoảng $2.500 \mathrm{~m})$. Tuyến 2: thu gom rác từ Viện $\mathrm{Ngô}$ đến phố Nguyễn Thái Học, khu vực trung tâm giáo dục thường xuyên Chợ Tre (khoảng 1.090m). Tuyến 3: thu gom rác phố Phượng Trì, khu vực trường tiểu học thị trấn Phùng (khoảng $800 \mathrm{~m}$ ). Tuyến 4: thu gom rác phố Phùng Hưng, chợ Phùng (khoảng $850 \mathrm{~m}$ ). Tuyến 5: thu gom rác phố Phan Đình Phùng, phố Thụy Ứng, phố Tây Sơn (khoảng $1300 \mathrm{~m}$ ). Tuyến 6: thu gom rác khu vực Gò Mèo, trường THPT Đan Phượng (khoảng $1200 \mathrm{~m})$. Tuyến 7: thu gom rác khu Đồng Sậy, cụm công nghiệp Phùng (khoảng 1350m).

Xã Tân Hội có 16 người thu gom với 5 tuyến thu gom chính. Rác sau khi được thu gom theo các tuyến được đưa đến điểm tập kết rác ngã ba Tân Hội và điểm tập kết trạm y tế Tân Hội (Kí hiệu trên sơ đồ: TKTH). Tuyến 1: duy trì vệ sinh tuyến đường trung tâm Tân Hội, thu gom rác khu vực UBND xã Tân Hội và trường Tiểu học Tân Hội A, trường THCS Tân Hội (khoảng 1650m). Tuyến 2: thu gom rác thôn Thượng Hội, cụm 11, cụm 12 , cụm 13 , đi qua vườn hoa Tân Hội và khu vực chợ Gối (khoảng 1100m). Tuyến 3: thu gom rác thôn Thúy Hội, cụm 7, cụm 8, cụm 9, cụm 10 (khoảng $1200 \mathrm{~m}$ ). Tuyến 4: thu gom rác thôn Phan Long, cụm 5, cụm 6 (khoảng 950m). Tuyến 5: thu gom rác thôn Vĩnh Kỳ, cụm 1, cụm 2, cụm 3, cụm 4 (khoảng 1300m).

Xã Phương Đình có 4 người thu gom với 4 tuyến thu gom được chia theo các thôn của xã. Rác sau khi được thu gom theo các tuyến, được đưa đến điểm tập kết thôn Phương Mạc và điểm 
tập kết nghĩa trang thôn Phương Mạc trên tỉnh 1ộ 417. Tuyến 1: thu gom rác của thôn La Thạch, thôn Phương Mạc, khu Cầu Gáo (khoảng $1350 \mathrm{~m})$. Tuyến 2: duy trì vệ sinh tỉnh lộ 417 đến hộ gia đình thôn Địch Thượng, thôn Địch Trung, thôn Địch Đình (khoảng 1800m). Tuyến 3: thu gom rác của thôn Cổ Thượng, từ tỉnh lộ 417 đến hộ gia đình (khoảng 980m). Tuyến 4: thu gom rác của thôn Cổ Hạ, thôn Ích Vịnh (khoảng $850 \mathrm{~m})$.

Xã Song Phượng có 9 công nhân thu gom rác với 4 tuyến thu gom chính. Rác sau khi được thu gom theo các tuyến thì được đưa đến điểm tập kết trường tiểu học và THCS Song Phượng (Kí hiệu trên sơ đồ: TKSP). Tuyến 1: duy trì vệ sinh đường đê và các tuyến đường liên xã (khoảng $2800 \mathrm{~m})$. Tuyến 2: thu gom rác của thôn Thống Nhất (khoảng 1350m). Tuyến 3: thu gom rác của thôn Tháp Thượng (khoảng 1200m). Tuyến 4: thu gom rác của thôn Thu Quế và thôn Thuận Thượng (khoảng 1200m).

Với hiện trạng vận chuyển rác thải của các phương tiện chuyên dùng hiện nay, một ngày công ty vận chuyển được khoảng 150 tấn rác/ngày. Theo kết quả điều tra các hộ gia đình thuộc 4 xã/thị trấn, hầu hết người dân cho rằng tần suất thu gom như vậy là hợp lý (chiếm 90\%), chỉ có $10 \%$ số hộ cho rằng tần suất thu gom không hợp lý.

Theo điều tra tại 4 xã/thị trấn trên địa bàn huyện, 96,67\% người dân đánh giá mức phí vệ sinh môi trường như vậy là chấp nhận được. 1,67\% có ý kiến mức phí như vậy là thấp; 1,67\% còn lại cho rằng mức thu phí như vậy là cao. Qua điều tra cho thấy, tỷ lệ thu gom rác trên địa bàn khá cao (khoảng 90\%), đảm bảo thu gom được một lượng lớn rác thải phát sinh tại khu vực $[9,10,11]$.

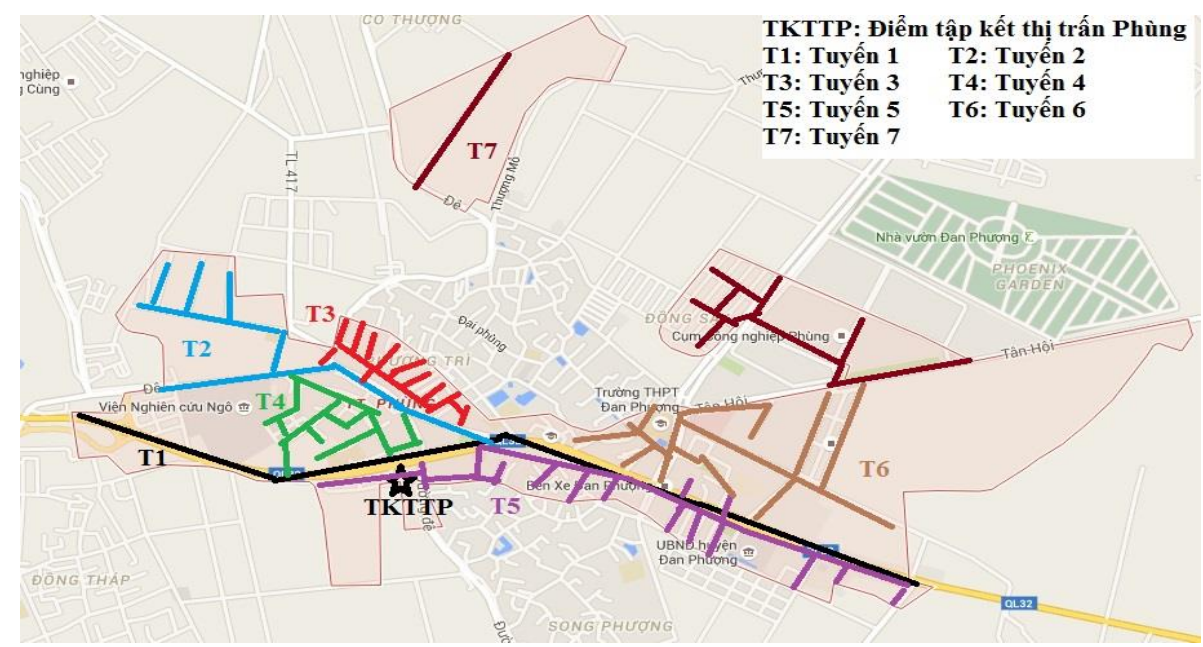

Hình 4. So đồ tuyến thu gom sơ cấp tại thị trấn Phùng

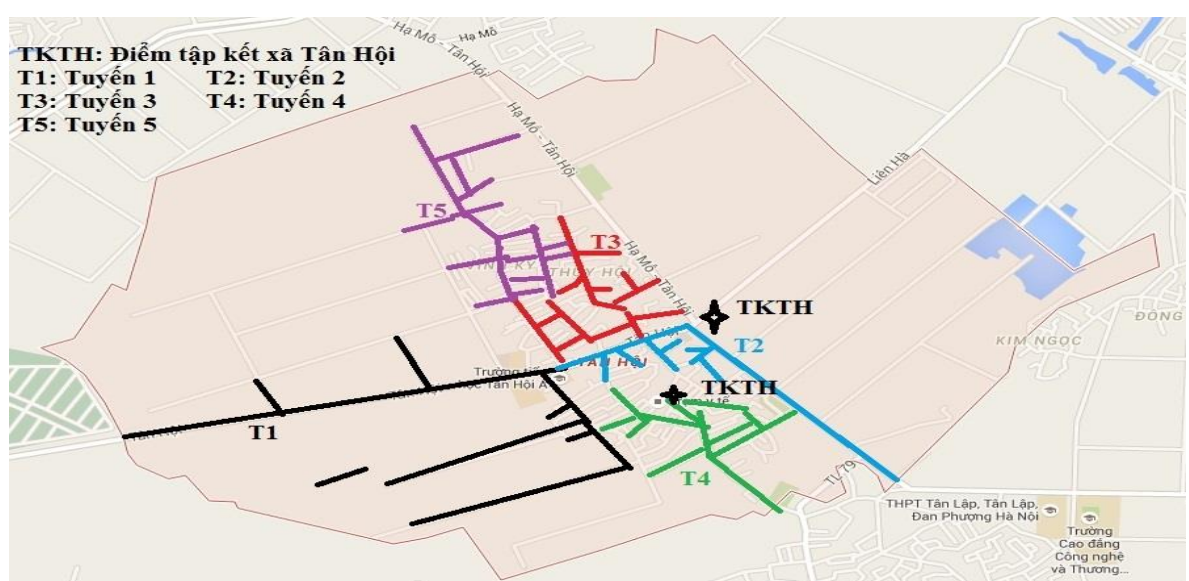

Hình 5. So đồ thu gom sơ cấp tại xã Tân Hội 


\section{BÀI BÁO KHOA HỌC}

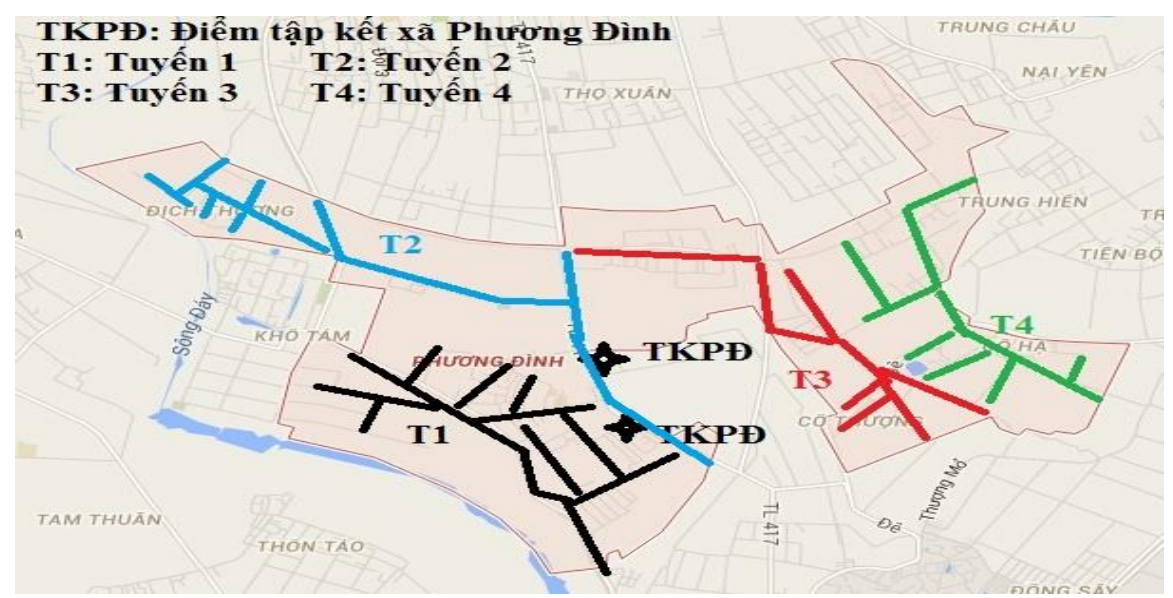

Hình 6. So đồ tuyến thu gom sơ cấp tại xã Phuoong Đình

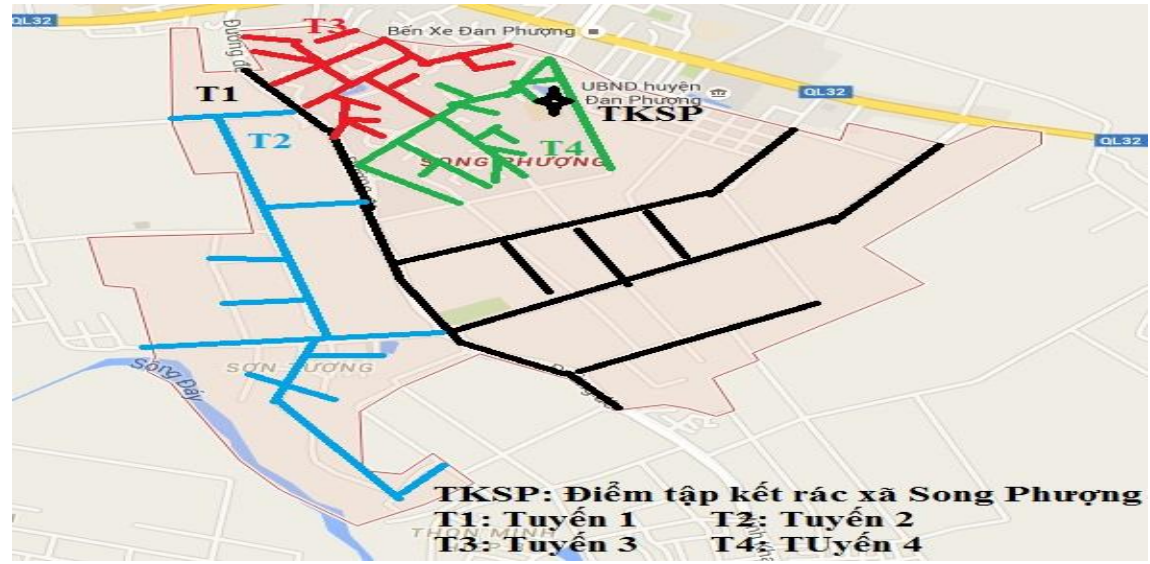

Hình 7. So đồ tuyến thu gom so cấp tại xã Song Phương

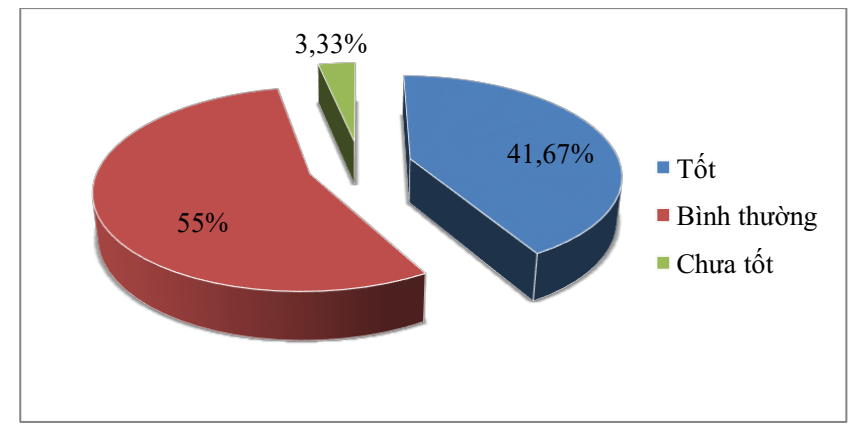

Hình 8. Đánh giá của người dân về chất lượng thu gom chất thải rắn sinh hoạt

3.4. Vận chuyển và xủ̉ lý CTRSH trên địa

\section{bàn huyện Đan Phuọng}

Phương tiện vận chuyển CTRSH thể hiện ở bảng 4 .

Tại khu vực nghiên cứu có 5 điểm tập kết rác sinh hoạt tạm thời, với tần suất vận chuyển rác là 1-2 lần/ngày theo các tuyến đã được quy định trước để tiết kiệm tối đa thời gian vẫn chuyển rác, đảm bảo thu gom và vận chuyển hết rác trong ngày. Các điểm tập kết đều nằm trên các trục đường lớn để thuận tiện cho các xe chuyên dụng di chuyển và dừng đỗ lấy rác cho lên xe trước khi vận chuyển đến nhà máy xử lý. Xe đẩy tay sau khi thu gom xong sẽ được công nhân cọ rửa sạch sẽ và được tập kết vào nơi quy định: Điểm ngã ba Tân Hội, trạm y tế xã Tân Hội ,nghĩa trang thôn Phương Mạc, thôn Phương Mạc, trường tiểu học và THCS Song Phượng, công an thị trấn. Một số ý kiến của người dân cho rằng vị trí tập kết rác tạm thời chưa hợp lý, 
các điểm tập kết này gần khu dân cư do đó thường phát sinh mùi rất khó chịu, gây bức xúc cho người dân xung quanh. Cần xây dựng các điểm tập kết sao cho hợp lý, không ảnh hưởng tới khu dân cư vừa thuận lợi cho công tác thu gom và vận chuyển.

Về xử lý rác sinh hoạt, nhà máy xử lý và chế biến rác Phương Đình nằm trên địa phận xã Phương Đình. Nhà máy xử lý và chế biến rác Phương Đình là nhà máy theo công nghệ lò đốt martin với công suất 300 tấn/ngày đêm. Rác thải sinh hoạt sau khi thu gom từ các nguồn phát sinh tập kết tại các điểm cẩu rác và được bốc lên xe chuyên dụng để vận chuyển đến nhà máy xử lý. Trước khi đưa và lò đốt, xe được đưa qua trạm cân điện tử để xác định trọng lượng rác trên xe, do không có công đoạn phân loại các chất thải tái chế và không tái chế được nên được đưa vào lò đốt tại nhà máy xử lý rác.

Về công tác tuyên truyền cho người dân về vấn đề vệ sinh môi trường, hoạt động tuyên truyền vấn đề rác thải nói riêng và vấn đề vệ sinh môi trường nói chung mới chỉ mang tính chất phát động, chưa được triển khai liên tục. Công tác tuyên truyền chủ yếu là nhờ các cuộc họp của chính quyền, hội phụ nữ, đoàn thanh niên, tần suất không thường xuyên của các bài viết tuyên truyền đọc trên loa phát thanh. Vì vậy, công tác tuyên truyền, giáo dục chưa phát huy được hiệu quả trên thực tế.

Bảng 4. Phuoong tiện dùng để vận chuyển CTRSH tại huyện Đan Phương

\begin{tabular}{clccc}
\hline STT & $\begin{array}{c}\text { Tên phương tiện, máy móc } \\
\text { chuyên dùng }\end{array}$ & Số lượng (chiếc) & Công suất & Số chuyến/ngày \\
\hline 1 & Ô tô cuốn ép chở rác HINO & 3 & $4,5 \mathrm{~T}$ & 2 \\
2 & Ô tô cuốn ép chở rác HINO & 4 & $6,0 \mathrm{~T}$ & 2 \\
3 & Ô tô cuốn ép chở rác DONGFENG & 1 & $7,5 \mathrm{~T}$ & 1 \\
4 & Ô tô cuốn ép chở rác DONGFENG & 1 & $12,0 \mathrm{~T}$ & 1 \\
5 & Ôt tô cuốn ép chở rác DAEWOO & 2 & $14 \mathrm{~T}$ & 2 \\
6 & Ô tô cuốn ép chở rác HINO & 1 & $5,0 \mathrm{~T}$ & 2 \\
& Tổng & $\mathbf{1 2}$ & & \\
& & &
\end{tabular}

Bảng 5. Kết quả dụ báo khối luợng CTRSH phát sinh và lương CTRSH được thu gom trên địa bàn huyện Đan Phương đến năm 2025

\begin{tabular}{lcccccc}
\hline Năm & $\begin{array}{c}\text { Tỷ lệ gia } \\
\text { tăng dân } \\
\text { số (\%) }\end{array}$ & $\begin{array}{c}\text { Dân số } \\
\text { (người) }\end{array}$ & $\begin{array}{c}\text { Tiêu chuẩn rác } \\
\text { thải trung bình } \\
\text { (kg/ng.ngđ) }\end{array}$ & $\begin{array}{c}\text { Lượng rác thải } \\
\text { sinh hoạt } \\
\text { (tấn/năm) }\end{array}$ & $\begin{array}{c}\text { Tỷ lệ thu gom rác } \\
\text { gongợng rác }\end{array}$ & $\begin{array}{c}\text { Lự gom } \\
\text { thúf găm) } \\
\text { (tân/năm) }\end{array}$ \\
\hline 2020 & 1,02 & 172.862 & 0,51 & 32178,26 & 0,9 & 28960,43 \\
2021 & 0,95 & 174.625 & 0,71 & 45254,07 & 1 & 45254,07 \\
2022 & 0,95 & 176.283 & 0,71 & 45683,74 & 1 & 45683,74 \\
2023 & 0,95 & 177.957 & 0,71 & 46117,56 & 1 & 46117,56 \\
2024 & 0,95 & 179.648 & 0,71 & 46555,78 & 1 & 46555,78 \\
2025 & 0,95 & 181.355 & 0,71 & 46998,15 & 1 & 46998,15 \\
Tổng & & & & & & $\mathbf{2 5 9 , 5 6 9 , 7 3}$ \\
\hline
\end{tabular}

\section{5. Đánh giá chung công tác quản lý \\ CTRSH}

Công tác thu gom cơ bản đáp ứng yêu cầu thực tiễn, dụng cụ, phương tiện, bố trí các tuyến thu gom, năng lực thu gom của công nhân.... đảm bảo công tác thu gom rác hiệu quả. Người dân đánh giá cao về tần suất, thời gian, tuyến thu gom rác hợp lý. Thu nhập của người dân tại thị trấn Phùng tăng nhờ phát triển buôn bán, kinh doanh là cơ hội để kêu gọi người dân đầu tư, ủng hộ cho những chương trình bảo vệ môi trường của thị trấn.

Tuy nhiên, khối lượng CTRSH trên địa bàn phát sinh ngày càng cao do tốc độ phát triển kinh 
tế, dân số tăng và quá trình đô thị hóa diễn ra nhanh, mức sống và nhu cầu tiêu dùng của người dân tăng. Thị trấn Phùng có chợ Phùng, là một chợ lớn của huyện phát triển kinh doanh đa dạng, với số lượng các sản phẩm ngày càng tăng để đáp ứng nhu cầu của người dân, xã Tân Hội và xã Song Phượng: làng nghề phát triển. CTRSH phát sinh trên địa bàn huyện chưa được phân loại tại nguồn nên tỷ lệ tái sử dụng, tái chế chất thải rắn thấp. Bên cạnh đó, chưa có sự phân công trách nhiệm rõ ràng trong công tác quản lý chất thải rắn của huyện, chưa thấy được vai trò của các cấp trong hệ thống quản lý. Hoạt động giám sát của nhà nước về chất thải rắn còn chưa đầy đủ. Hệ thống pháp lý chưa hoàn thiện, thiếu các quy định, chính sách phù hợp trong việc quản lý CTRSH; thiếu sự đầu tư kinh phí ngân sách của các cấp chính quyền ngành trong việc quản lý chất thải, xây dựng cơ sở hạ tầng thu gom, vận chuyển và xử lý CTRSH; chưa có định hướng chiến lược dài hạn; hạn chế trong quản lý các điểm tập kết, xử lý đạt hiệu quả. Hiện chưa có sự liên kết giữa các hộ gia đình, công nhân thu gom và các tổ chức đoàn thể; chưa có sự liên kết chặt chẽ giữa chính quyền và các đoàn thể trong công tác tuyên truyền nâng cao ý thức bảo vệ môi trường của người dân.

\section{6. Đề xuất giải pháp nâng cao hiệu quả quản lý CTRSH}

Giải pháp về chính sách cần tập trung vào xây dựng những quy định chung về quản lý CTRSH; xây dựng kế hoạch thực hiện đồng bộ các thiết bị, công cụ thu gom từ khâu phân loại tại các hộ dân và khu vực công cộng đến việc thu gom đưa về nơi trung chuyển tập trung, các xe vận chuyển rác đến các khu vực xử lý rác đối với từng loại rác thải đã được phân loại; tăng ngân sách cho hoạt động tuyên truyền và bảo vệ môi trường, phải có quỹ môi trường để chi trả cho các hoạt động khuyến khích và giải quyết sự cố môi trường ngay tại địa phương. Giải pháp nâng cao năng lực của hệ thống quản lý nhà nước về bảo vệ môi trường; đào tạo nâng cao năng lực về cách thức phân loại rác tại nguồn, tái sử dụng, tái chế, quản lý chất thải một cách bền vững và giáo dục cộng đồng trong quản lý chất thải rắn... Giải pháp tuyên truyền giáo dục, nâng cao nhận thức của người dân về vấn đề quản lý rác thải, khuyến khích thay đổi hành vi, xây dựng lối sống thân thiện với môi trường của người dân địa phương. Tuyên truyền lợi ích và thực hiện các chương trình thúc đẩy người dân mua các sản phẩm có ít bao bì, tái sử dụng các túi đựng nhiều lần, sử dụng các loại bao bì dễ phân hủy, giảm dần thói quen sử dụng túi nilon khó phân hủy.

Đề xuất vị trí các trạm trung chuyển chính thống. Tại thị trấn Phùng: Chọn vị trí khu đất trống gần khu sinh thái cao cấp thị trấn Phùng. Đây là vị trí khu biệt thự mới đang xây dựng, xung quanh là cụm công nghiệp và tập trung nhiều nhà nghỉ, quán cafe,... trong tương lai sẽ là nguồn phát sinh CTRSH lớn. Khu vực này có hạ tầng giao thông thuận tiện cho công tác thu gom, vận chuyển rác thải. Tại xã Tân Hội: Chọn vị trí khu đất trống tại khu công nghiệp làng nghề. Khu vực này gần khu dân cư, tập trung nhiều công ty, doanh nghiệp và đang ngày càng phát triển, lượng CTRSH phát sinh lớn. Do vậy, nên cần có một vị trí trung chuyển rác để thuận tiện cho việc thu gom và tập kết rác của các xe gom đẩy tay tại khu vực. Tại xã Phương Đình: Hiện tại xã Phương Đình có 2 vị trí tập kết rác, trong đó có một điểm tập kết nằm giữa cánh đồng, sát con đường dẫn vào làng. Là một vị trí thuận lợi để lựa chọn làm trạm trung chuyển chính thống. Vị trí này có nền bê tông, được xây bờ bao xung quanh, cách khu dân cư khoảng 1000m, giao thông thuận lợi cho việc tập kết rác và việc dừng đỗ lấy rác của xe cuốn ép. Tại xã Song Phượng: Khu vực đất trống tại thôn Thuận Thượng, nằm dưới chân đê. Khu vực này tập trung đông dân cư, nhiều hộ gia đình làm nghề kẹo lạc. Xây dựng chiến lược, định hướng cụ thể về các giải 
pháp công nghệ đối với rác thải hữu cơ, rác thải tái chế phù hợp điều kiện thực tiễn, công nghệ tiên tiến trên thế giới, đảm bảo tiêu chuẩn môi trường.

\section{Kết luận}

Lượng CTRSH từ các nguồn phát sinh trên địa bàn huyện Đan Phượng, thành phố Hà Nội ước khoảng 88 tấn/ngày. Lượng CTRSH được thu gom khoảng 75,6 tấn/ngày. Tỷ lệ thu gom khá cao, khoảng $90 \%$. Do các xã này có mức sống khá tương đồng do đó lượng chất thải rắn sinh hoạt phát sinh trên đầu người trung bình là $0,58 \mathrm{~kg} /$ người $/$ ngày. Thành phần rác thải sinh hoạt chủ yếu là chất thải hữu cơ chiếm $50 \%$ $54 \%$. Các thành phần còn lại chiếm tỷ lệ nhỏ (như nilon, nhựa là 11,5\% - 14,5\%). Đa số ý kiến đánh giá của người dân, thời gian và tần suất thu gom như vậy là hợp lý, công tác thu gom đạt hiệu quả, đảm bảo mỹ quan đô thị. Chất thải rắn hiện nay chưa được phân loại rác tại nguồn; sau thu gom được chuyển đến nhà máy xử lý và chế biến rác Phương Đình để xử lý bằng phương pháp đốt. Các giải pháp đề xuất trong nghiên cứu tập trung vào giải pháp về chính sách; nâng cao năng lực của hệ thống quản lý nhà nước về bảo vệ môi trường; tuyên truyền giáo dục, nâng cao nhận thức; công nghệ, bố trí hợp lý vị trí tập kết, trạm trung chuyển; công nghệ xử lý phù hợp thực tiễn và xu hướng phát triển.

\section{Tài liệu tham khảo}

1. Công ty cổ phần môi trường Tân Hội (2015), Báo cáo số: 22/BC-MTTH ngày 29/12/2015 của Công ty cổ phần môi trường Tân Hội.

2. Phòng Tài nguyên và Môi trường huyện Đan Phượng, Báo cáo năm 2017-2019.

3. Hợp tác xã Thành Công (2019), Báo cáo tổng kết kết quả hoạt động năm 2019 của Hợp tác xã Thành Công.

4. Tổng cục môi trường (2018), Báo cáo môi trường quốc gia về quản lý chất thải rắn.

5. Nghị định 38/2015/NĐ-CP ngày 24/04/2015 của Chính Phủ về Quản lý chất thải rắn và phế liệu.

6. Nghị định 59/2007/NĐ-CP ngày 9/04/2007 của Chính Phủ về Quản lý chất thải rắn.

7. Trần Hiếu Huệ (2001), Quản lý chất thải rắn, NXB xây dựng, Hà Nội.

8. Nguyễn Xuân Nguyên (2004), Công nghệ xủ lý rác thải và chất thải rắn, NXB khoa học kỹ thuật.

9. UBND huyện Đan Phượng (2018), Báo cáo dân số.

10. UBND thành phố Hà Nội (2013), Quyết định số 7936/QĐ-UBND ngày 27/12/2013 về việc quy định mưc thu dịch vu vệ sinh đối với chất thải rắn công nghiệp thông thuờng trên địa bàn thành phố Hà Nội.

11. UBND thành phố Hà Nội (2014), Quyết định số 44/2014/QĐ-UBND ngày 20/08/2014 về việc thu phí vệ sinh đối với chất thải rắn sinh hoạt của hộ gia đinh, cá nhân trên địa bàn thành phố Hà Nội. 


\title{
BÀI BÁO KHOA HỌC
}

\section{Status assessment and solutions of management to domestic solid wastes in Dan Phuong district, Ha Noi}

\author{
Pham Thi To Oanh ${ }^{1}$ \\ ${ }^{1}$ Vietnam Cooperative Alliance
}

\begin{abstract}
The amount of domestic solid waste in Dan Phuong district, Ha Noi city is about 88 tons per day, in which, 90\% of it is collected. In average, waste generation coefficient per one person is $0,58 \mathrm{~kg} /$ person/day. The rate of organic component is 50-54\%. The rate of other components is small (nilon and plastic are 11,5\%-14,5\%). Investigate results shown as $90 \%$ of local residents evaluate on suitabble collection times and frequencies, collection is effective, reaching urban beauty. In present, solid wastes still are n't classificated at source and after collecting and taking to Phuong Dinh factory of wastes treatment and process, which are treated by burning method. However, restriction in management of domestic solid waste such as regulations, information, propaganda, suitable orientation, gathering locations, treatment technologies,... Resolutions are also suggested to policies; enhancing of capacity of state management system on evironmental protection such as education propaganda, raising awareness; technology, gathering location, transit station are proposed to incresing effective of solid waste management in district scale. This study contributes to giving solutions of solid wastes management in larger scale in Ha Noi City.
\end{abstract}

Keywords: Domestic solid waster, Status, Solution, Management, Treatment. 